\title{
ANALYSIS OF FARMERS SATISFACTION ON HYBRID RICE SEED MAPAN P-05 IN PENDEM VILLAGE, JUNREJO SUBDISTRICT, BATU CITY
}

\author{
Sri Wahyuni ${ }^{1, *}$, Ratya Anindita, and Condro Puspo Nugroho \\ Agricultural Socio-Economics Departement, Faculty of Agriculture, University of Brawijaya, Indonesia \\ *corresponding author: sriwahyuni190813@gmail.com
}

\begin{abstract}
The purpose of this research is to describe the knowledge of farmers about the seed of hybrid rice Mapan P-05, to analyze the conformance of performance and importance level, and to analyze farmers' satisfaction to hybrid rice seeds of Mapan P-05. Sampling method used is census, where all the population members are farmers who use the seed of Mapan P-05. Methods of data analysis use descriptive analysis and quantitative analysis, which are IPA (Importance Performance Analysis) and CSI (Customer Satisfaction Index). The results found that the conformance level of performance and importance of hybrid rice seed Mapan P-05 is $80.2 \%$; while the level of overall satisfaction is $62.06 \%$. From the CSI, the attributes which should be considered by producers are the price, the seeds productivity, the seeds availability and the harvest age.
\end{abstract}

Keywords: consumer satisfaction, IPA, CSI, hybrid rice seed Mapan P-05

\section{INTRODUCTION}

Rice is an important commodity as the main food producers in Indonesia. Increasing population growth each year would make the request for rice production also increased. So the growth in rice production should be higher or at least equal to the rate of population growth. According to the BPS (2017), showed that the rate of growth in rice production is fluctuate, and had experienced a decline in production in 2014, caused by the decline in the broad area of harvest. This makes Indonesia should continue to seek the production of rice in order to fullfil the needs.

Many efforts can be made to encourage increased production, one of them is the use of seed. The seed is one factor that plays an important role in the activities of rice cultivation. One use of excelent seed here is the use of hybrid rice seeds. According to Satoto et al., (2009), hybrid seeds is a seed which is used for plant production in the form of the seed of the first generation (F1) derived from the results of a cross between different elders are chosen through a selection. Hybrid rice is expected to be one of the solutions in the increase of rice production in Indonesia. However the use of hybrid rice seed is still very small, most growers prefer to use varieties of non hybrid.

The low usage of the hybrid rice seed is needed to be noticed because it deals with the alignment of the quality hybrid rice in hopes of farmers. According to Kotler and Armstrong (2009), consumers will be satisfied if the performance of the product in accordance with their expectations. The use of hybrid rice seeds are still low is generally influenced by less performance attributes of seeds so it can affect the level satisfaction of farmers against the hybrid rice seed.

Related research consumer satisfaction has been done, one of which is about satisfaction against seed potatoes certified (Wicaksana, 2013), Corned Pronas Production PT CIP (Sukardi and Chandrawatisma, 2008), and Gulaku by Anggraini, et al. (2013). The study shows that satisfaction was strongly influenced by the performance of the attributes of the product.

Based on the existing problems in the fields and in the past research, then the purpose of this 
research is (1) to describe the knowledge of farmers about the seed of hybrid rice Mapan P-05, (2) to analyze the conformance level of performance and importance hybrid rice seed Mapan P-05, and (3) to analyze farmers satisfaction to hybrid rice seeds Mapan P-05. So hopefully this research can serve as evaluation material for a company to improve the hybrid rice seed products Mapan P-05.

\section{RESEARCH METHODS}

Research location was selected purposively in Pendem village, Junrejo subdistrict, Batu city and implemented in August 2017. This research uses census technique, where all the population members which is 42 farmers are the respondents. The primary data are coming from interview using questionnaire and observation. Secondary data are obtained from literatures, such as Statistics Indonesia (BPS), previous researches, and others.

The data are represented descriptively and analyzed for getting information regarding farmers' satisfaction toward hybrid rice seed. Descriptive analysis was used to describe and explain the characteristics of farmers and knowledge of farmers against hybrid rice seed Mapan P-05. While the other quantitative analysis is used to analyze the conformance of performance and importance, and the level of farmers satisfaction against hybrid rice seed Mapan P-05.

Based on previous research in customer satisfaction by Wicaksana (2013), Sukardi and Chandrawatisma (2008), and Anggraini et, al. (2013), this research used IPA (Importance Performance Analysis) and CSI (Customer Satisfaction Index). Before use IPA and CSI, the test instrument use by the validity test and realibility test. The validity test must show the value of $r$ count $>r$ table so the data can be valid. Meanwhile the reability test must show the value of Alpha Cronbach's > 60\% (0.6) (Asnawi and Masyhuri, 2011).

\section{IPA (Importance Performance Analysis)}

Importance Performance Analysis is a method to analyze the conformance level of importance and performance of product. According to Supranto (1997), as for the formula used to measure conformance level are:

$$
C L i=\frac{X i}{Y i} \times 100 \%
$$

Description:

$\mathrm{CLi}=$ conformance level of importance and performance hybrid rice seed Mapan p-05

$\mathrm{Xi}=$ score assessment of performance products hybrid seeds Mapan p-05

$\mathrm{Yi}=$ score assessment of importance farmers against hybrid seeds Mapan p-05

Further results from the calculation, it is averaged and formulated in a Cartesian diagram. Simplification of the formula to calculate the average are:

$$
\bar{Y}=\frac{\Sigma Y i}{n} \text { and } \bar{X}=\frac{X i}{n}
$$

Description:

$\bar{X}=$ average value of performance attribute-i

$\bar{Y}=$ average value of importance attribute- $i$

$\mathrm{Xi}=$ total score performance level of attribute- $\mathrm{i}$

$\mathrm{Yi}=$ total score importance level of attribute- $\mathrm{i}$

$\mathrm{n}=$ number of data consumer

The results of the above calculation can be made into a cartesian diagram, that diagram shows which attributes of hybrid rice seed Mapan P-05 which can fullfil importance of consumers. This diagram is divided into four sections which intersect perpendicular at the point $(\bar{X}, \bar{Y})$, at that point retrieved the following formula:

$$
\overline{\bar{X}}=\frac{\Sigma \overline{X \imath}}{K} \text { and } \overline{\bar{Y}}=\frac{\Sigma \overline{Y l}}{K}
$$

Description:

$\overline{\bar{X}}=$ average score from the average rate of performance of all attributes

$\overline{\bar{Y}}=$ average score from the average rate of importance of all attributes

$\mathrm{K}=$ the number of attributes that are researched

The next attributes are spelled out and divided into four parts in a cartesian diagram as in figure 1 .

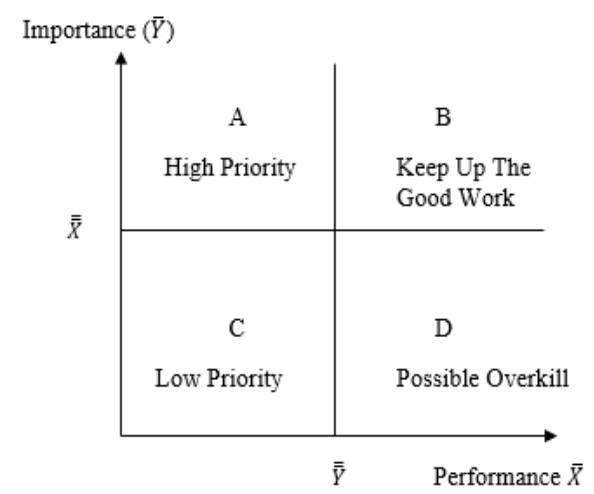

Figure 1. Cartesian Diagram IPA Source : Supranto (1997)

Volume 18, Number 1 (2018): 1-6 


\section{CSI (Customer Satisfaction Index)}

Customer Satisfaction Index is a method for measuring the satisfaction level of the farmers as a whole to look at the importance of hybrid rice seed Mapan P-05. According to Wicaksana (2013) to know the magnitude of the CSI steps that must be performed are as follows:

1) Define MIS (Mean Important Score) and MSS (Mean Satisfaction Score). This value is obtained from the average value of the level of importance and the value of the average performance of each respondent.

$$
\begin{aligned}
M I S & =\frac{\Sigma_{i=1}^{n} Y_{i}}{n} \\
M S S & =\frac{\Sigma_{i=1}^{n} X i}{n}
\end{aligned}
$$

Description:

$\mathrm{n}$ = number of respondents

$Y_{i}=$ value of importance attribute- $i$

$X_{i}=$ value of performance attribute- $i$

2) Create a WF (Weight Factors), this weighting is the percentage value MIS per attribute to the total MIS the entire attribute.

$W F_{i}=\frac{M I S_{i}}{\Sigma_{i=1}^{p} M I S_{i}} \times 100 \%$

Description:

$\mathrm{p}=$ the number of attribute importance

$\mathrm{i}=$ attribute- $\mathrm{i}$

3) Create WS (Weight Score), namely the weighting of the results of the multiplication between WF (Weight Factor) with MSS (Mean Satisfaction Score)

$$
W S_{i}=W F_{i} \times M S S_{i}
$$

4) Calculate the total of WS (Weight Score) attribute-1 (a-1) up to the last attribute (a-p) called WAT (Weight Average Total)

5) Calculate the percentage of the CSI (Customer Satisfaction Index), that is the Total maximum scale divided Weight used, in this case using the maximum of scale 5 .

$$
C S I=\frac{\Sigma_{i=1}^{p} W S_{i}}{H S} \times 100 \%
$$

Description:

$\mathrm{P}=$ attribute-p

$\mathrm{HS}=$ maximum scale used

From the results of the calculations are done, the satisfaction level of farmers as a whole can be categorized based on the criteria of CSI (Customer Satisfaction Index) are presented in table 1.
Table 1. The Criteria of Customer Satisfaction Index

\begin{tabular}{ll}
\hline CSI Rating $(\%)$ & Criteria of CSI \\
\hline $0<\mathrm{CSI} \leq 34$ & Dissatisfied \\
$35<\mathrm{CSI} \leq 50$ & Less satisfied \\
$51<\mathrm{CSI} \leq 65$ & Quite satisfied \\
$66<\mathrm{CSI} \leq 80$ & Satisfied \\
$81<\mathrm{CSI} \leq 100$ & Very satiesfied
\end{tabular}

Sumber : Wicaksana, (2013)

\section{RESULTS AND DISCUSSION}

Farmers' knowledge about hybrid rice seeds Mapan P-05

Hybrid seeds in Pendem village have long been known by farmers, before the introduction of hybrid seeds Mapan P-05 in Pendem village, farmers have already known another hybrid seeds. Then in about the year 2010 was recognized another type of hybrid rice seed Mapan P-05 through public awareness, the seeds are slowly starting to be known and used by farmers in the village of Pendem.

Pendem Village farmers is gaining knowledge about hybrid rice seed Mapan P-05 from friends $(40.5 \%)$, and extension officers $(35.7 \%)$ while the rest got information from media information such as the internet and farmer groups $(23.8 \%)$. The exchange of information from farmers acquires knowledge of hybrid rice seed Mapan P-05. Once farmers know about the seeds, they are interested to try so they can know the results directly. Most of the farmers in the village of Pendem had already knowledge of hybrid rice seed Mapan P-05.

The conformance level of performance and importance

Methods of Importance Performance Analysis (IPA) was used to find out how the level of conformity between the performance of hybrid rice seed Mapan P-05 with the importance of farmers are against the expected hybrid rice seed Mapan $\mathrm{P}$ 05. Following is the result of the analysis using Importance Performance Analysis (IPA) along with a Cartesian diagram mapping on Table 2.

Based on Table 2 it can be seen that each variable has a different value. The average value of the conformance level is $80.2 \%$ of 10 variables. Each variable has a different level of conformance due to the performance levels and importance. 
Table 2. The Conformance Level of Importance and Performance Hybrid Rice Seed Mapan P-05

\begin{tabular}{|c|c|c|}
\hline Dimension & Variable & $\begin{array}{l}\text { Level of } \\
\text { Confor- } \\
\text { mance } \\
(\mathrm{CLi})(\%)\end{array}$ \\
\hline \multirow[t]{2}{*}{ Performance } & 1. Productivity & $57.2 \%$ \\
\hline & 2. Harvest age & $68.2 \%$ \\
\hline \multirow[t]{2}{*}{$\begin{array}{l}\text { Conformance to } \\
\text { specification }\end{array}$} & $\begin{array}{l}\text { 3. Resistance to } \\
\text { pests and } \\
\text { diseases }\end{array}$ & $78.5 \%$ \\
\hline & $\begin{array}{l}\text { 4. Resistant fall } \\
\text { plants }\end{array}$ & $93.9 \%$ \\
\hline Durability & $\begin{array}{l}\text { 5. Expired of } \\
\text { seed }\end{array}$ & $122.4 \%$ \\
\hline \multirow[t]{3}{*}{$\begin{array}{l}\text { Perceived } \\
\text { quality }\end{array}$} & $\begin{array}{l}\text { 6. Purchase } \\
\text { price of the } \\
\text { seed }\end{array}$ & $37.6 \%$ \\
\hline & $\begin{array}{l}\text { 7. Selling price } \\
\text { of grain }\end{array}$ & $90.1 \%$ \\
\hline & 8. Grain loss & $89.8 \%$ \\
\hline \multirow[t]{2}{*}{ Serviceability } & $\begin{array}{l}\text { 9. Seed } \\
\text { availability }\end{array}$ & $60.2 \%$ \\
\hline & $\begin{array}{l}\text { 10. Seed } \\
\text { information }\end{array}$ & $103.8 \%$ \\
\hline Total & & $801.8 \%$ \\
\hline Average & & $80.2 \%$ \\
\hline
\end{tabular}

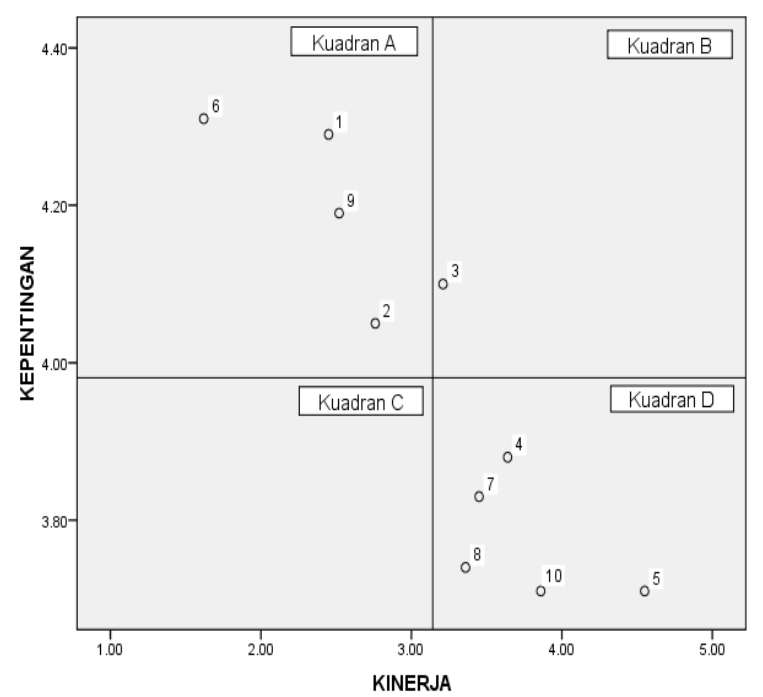

Figure 2. Cartesian Diagram of Performance Level and Importance Level of Hybrid Rice Seed Mapan P-05

The following is doing the mapping using the Cartesian diagram to find out the position of a variable, so it can be determined how to repair effort that needs to be done to these variables.

Based on figure 2 shows that in A quadrant, there are 5 variables, quadrant $B$ there is 1 variable, quadrant $\mathrm{C}$ there are no variables, and quadrant $\mathrm{D}$, there 5 variables. In the following table are the variables that are included in the Cartesian diagram.

Table 3. Variable Based on Mapping of Cartesian Diagram

\begin{tabular}{|c|c|c|}
\hline Quadrant & Interpretation & Variable \\
\hline Quadrant A & $\begin{array}{l}\text { High } \\
\text { priority }\end{array}$ & $\begin{array}{l}\text { Productivity (1), } \\
\text { harvest age (2), } \\
\text { purchase price of } \\
\text { the seed (6), seed } \\
\text { availability (9) }\end{array}$ \\
\hline Quadrant B & $\begin{array}{l}\text { Keep up the } \\
\text { good work }\end{array}$ & $\begin{array}{l}\text { resistance to pests } \\
\text { and diseases ( } 3 \text { ) }\end{array}$ \\
\hline Quadrant C & Low priority & \\
\hline Quadrant D & $\begin{array}{l}\text { Possible } \\
\text { overkill }\end{array}$ & $\begin{array}{l}\text { Resistant fall plants } \\
(4), \text { the Expired of } \\
\text { seed (5), selling } \\
\text { price of grain ( } 7) \text {, } \\
\text { grain loss (8), seed } \\
\text { information (10) }\end{array}$ \\
\hline
\end{tabular}

1) Quadrant A (High priority)

Quadrant A shows the variables that affect the satisfaction of farmers but in practice, the variable performance has not got fullest attention so that it can be improved further. The variables that are in this quadrant include productivity, harvest age, purchase price of the seed, and seed availability.

2) Quadrant B (Keep up the good work)

Quadrant B consists of variables that have a level of performance and a high level of importance, and have been able to influence the satisfaction of farmers, so that the variable must be maintained. Variables included in the quadrant B is resistance to pests and diseases. Hybrid seeds Mapan P-05 where farmers are more resistant to pests and diseases than with local seeds. Although both stricken with pests and diseases which are quite severe, the rice production Mapan P-05 are still a little bit more. Therefore, this variable must be maintained or further improved again to keep having a good production.

\section{3) Quadrant C (low priority)}

The variables in this quadrant are a variable that has a low priority to do repairs. Variable in quadrant $\mathrm{C}$ has a low importance and low level of performance anyway. In this research, there is no variables in quadrant $C$. 
4) Quadrant D (possible overkill)

Quadrant D shows the variables that have a low importance, but have a high level of performance. So variable in this quadrant can affect the satisfaction of farmers. The variables in this quadrant are resistant fall plants, expired of seed, selling price of grain, grain loss, and information about the seeds.

\section{The farmers' satisfaction level (customer satisfaction index)}

Customer Satisfaction Index (CSI) is a measurement tool to know the level of overall satisfaction of a product. To get the value of the CSI, must first find out the average rating score of importance (MIS), weight factor (WF), the average value of performance score (MSS), and weight score (WS). The calculation of the Customer Satisfaction Index (CSI) can be seen in Table 4.

Table 4. The Calculation of Customer Satisfaction Index (CSI) Hybrid Seed Mapan P-05

\begin{tabular}{|c|c|c|}
\hline Dimension & Variable & $\begin{array}{c}\text { Weight } \\
\text { Score } \\
\text { (WS) }\end{array}$ \\
\hline \multirow[t]{2}{*}{ Performance } & 1. Productivity & 0.26 \\
\hline & 2. Harvest age & 0.28 \\
\hline \multirow[t]{2}{*}{$\begin{array}{l}\text { Conformance to } \\
\text { specification }\end{array}$} & $\begin{array}{l}\text { 3. Resistance to } \\
\text { pests and diseases }\end{array}$ & 0.33 \\
\hline & $\begin{array}{l}\text { 4. Resistant fall } \\
\text { plants }\end{array}$ & 0.36 \\
\hline Durability & 5. Expired of seed & 0.42 \\
\hline \multirow[t]{3}{*}{$\begin{array}{l}\text { Perceived } \\
\text { quality }\end{array}$} & $\begin{array}{l}\text { 6. Purchase price of } \\
\text { the seed }\end{array}$ & 0.18 \\
\hline & $\begin{array}{l}\text { 7. Selling price of } \\
\text { grain }\end{array}$ & 0.33 \\
\hline & 8. Grain loss & 0.32 \\
\hline \multirow[t]{2}{*}{ Serviceability } & 9. Seed availability & 0.27 \\
\hline & 10. Seed information & 0.36 \\
\hline Total & & 3.10 \\
\hline Customer Satis & iction Index & 62.06 \\
\hline
\end{tabular}

Based on Table 4, it can be seen that the value of the Customer Satisfaction Index (CSI) is $62.06 \%$. The value entered in the criteria quite satisfied, accordance with the criteria of CSI in Wicaksana (2013) that range $51 \%<\mathrm{CSI} \leq 65 \%$ included in quite satisfied. The value should be increased again in order to approach the number 100 or enter in the satisfied category. To increase the value of the CSI can be done by improving the performance attributes that are less. Based on the analysis of the IPA performance attributes that less is productivity, age of harvest, the purchase price of the seed, and seed availability in the quadrant A. Whereas to quadrant $\mathrm{B}$ and $\mathrm{D}$ performance need to be maintained so that the value of the CSI not descends.

\section{CONCLUSION}

The conclusions of this research are:

1) Knowledge of the farmers of hybrid rice seeds about Mapan P-05 in the Pendem village has been good enough. They get information about seed Mapan P-05 from friends $(40.5 \%)$, and extension officers $(35.7 \%)$ while the other got information from the internet and farmer groups $(23.8 \%)$

2) The level of conformance between performance and the importance to hybrid rice seed of Mapan P-05 is $80.2 \%$ from the 10 attributes of the product. From the results of the mapping on a Cartesian diagram, there are 5 attributes included in quadrant $\mathrm{A}$ that is productivity, harvest age, purchase price of the seed, and seed availability. Those attributes should get more attention so that its performance can be increased. In quadrant B there is resistance to pest and disease of attributes that should be preserved because it has a value that has already been in compliance. While in quadrant $\mathrm{D}$ there are 5 attributes those are expired of seed, selling price of the grain, grain loss, and seed information

3) The Value of farmers satisfaction to hybrid rice seed Mapan P-05 overall majority amount $62.06 \%$ include in the scale range $51 \%<\mathrm{CSI} \leq$ $65 \%$. From these results it can be concluded that farmers who use hybrid rice seeds Mapan P-05 are quite satisfied to the seed attribute. The value should be increased again in order to approach the satisfied category. To increase the value of the CSI can be done by improving the performance attributes that are less in accordance with the results of the analysis of IPA.

From this research so that the suggestions are:

1) Producer need to make improvements on the attribute there are productivity, harvest age, purchase price of the seed, and seed availability so that it performs better. 
2) Government can give an evaluation of the national seed industry toward more related quality problems and also the appropriate seed prices in order so not to disadvantage farmers.

\section{REFERENCES}

Anggraini, et al. (2013). Tingkat Kepuasan dan Loyalitas Konsumen Gulaku di Kota Bandar Lampung. JIIA, Volume 1 No. 2 April 2013

Asnawi, Nur dan Masyhuri. (2011). Metodologi Riset Manajemen Pemasaran: Dilengkapi dengan Contoh Hasil Penelitian. UIN Maliki Press. Malang

Badan Pusat Statistik. (2017). Produksi Padi Indonesia. online. http://bps.go.id. Diunduh pada 10 Januari 2017

Kotler, Philip dan Gary Amstrong. (2009). PrinsipPrinsip Pemasaran. Edisi ke 12. Erlangga. Jakarta
Kotler, Philip dan Kevin Lane Keller. (2009). Manajemen Pemasaran. Erlangga. Jakarta

Satoto et, al. (2009). Prospek Pengembangan Padi Hibrida. Balai Besar Penelitian Tanaman Padi.

Sukardi dan Chodilis Chandrawatisma. (2008). Analisis Tingkat Kepuasan Pelanggan Terhadap Produk Corned Pronas Produksi PT CIP, Denpasar Bali. Jurnal teknologi pertanian Vol. 18(2). 116-117

Supranto, J. (1997). Pengukuran Tingkat Kepuasan Pelanggan untuk Menaikkan Pangsa Pasar. Rineka Cipta. Jakarta

Wicaksana, Bayu Eka. (2013). Analisis Sikap dan Kepuasan Petani dalam Menggunakan Benih Kentang Bersertifikat (Kasus Di Kecamatan Bumiaji, Kota Batu). Jurnal Habitat Volume XXIV, No. 3, Bulan Desember 2013 